\title{
Optimization of root proliferation medium for Hyoscyamus niger L.
}

\author{
Marvin Loke Kah Hong, Arvind Bhatt, Ning Shuping and Chan Lai Keng* \\ School of Biological Sciences, University Sains Malaysia, 11800 Penang, Malaysia.
}

Accepted 24 November, 2010

\begin{abstract}
Untransformed root culture of Hyoscyamus niger could be induced from petiole explants on solid MS medium supplemented with $2.0 \mathrm{mg} \mathrm{I}^{-1}$ IBA after four weeks of incubation under continuous light of 32.5 $\mu \mathrm{mol} \mathrm{m} \mathrm{m}^{-2} \mathrm{~s}^{-1}$. However, liquid MS medium supplemented with $0.5 \mathrm{mg}^{-1}$ IBA was found to be better for root proliferation. Cultures at the third subculture cycle during root proliferation showed maximum root biomass production either under continuous light $(3.69 \pm 1.00 \mathrm{~g})$ or in total darkness $(4.02 \pm 0.94 \mathrm{~g})$. Step-wise optimization of culture medium components was carried out by manipulating the MS macronutrients, myo-inositol, Fe-EDTA and sucrose. The optimum root biomass producing medium was established as modified MS medium containing altered concentrations of macronutrients (15.0 mM $\mathrm{NH}_{4} \mathrm{NO}_{3}, 33.1 \mathrm{mM} \mathrm{KNO}{ }_{3}, 3.19 \mathrm{mM} \mathrm{CaCl} .2 \mathrm{H}_{2} \mathrm{O}, 1.9 \mathrm{mM} \mathrm{MgSO}{ }_{4} .7 \mathrm{H}_{2} \mathrm{O}$ and $1.4 \mathrm{mM} \mathrm{KH}_{2} \mathrm{PO}_{4}$ ), $9.6 \mathrm{mM}$ myoinositol, $0.1 \mathrm{mM}$ Fe-EDTA and $3 \%$ sucrose supplemented with $0.5 \mathrm{I}^{-1} \mathrm{mg} \mathrm{IBA}$.
\end{abstract}

Key words: Hyoscyamus niger, modified MS medium, macronutrient, root proliferartion, root biomass.

\section{INTRODUCTION}

Hyoscyamus niger L. (Family Solanaceae), commonly known as black henbane, is an important medicinal plant, distributed in China, Afghanistan, India, Japan, Korea, South West Asia, North Africa and throughout Europe (Sajeli et al., 2006). It is one of the earliest medicinal plants used by the Greeks and Orientals (Enriz, 2005) and extensively used for the treatment of rabies, fevers, bronchitis, renal colic, coughs and spasms as sedative, anodyne, antispasmodic and stimulant (Schultes and Smith, 1976; Harrison and Bartels, 2006). H. niger contains two distinguished tropane alkaloids, hyoscyamine and scopolamine and both the compounds possess potential acute or chronic toxicity (Winston, 1994; Li et al., 2003; Vike et al., 2008). It has been reported that tropane alkaloids are mostly synthesized in the young root cells and then transported to the aerial parts (Hashimoto et al., 1991). However, as a temperate plant, the temperature and seasonal factors limit its potential to be mass-produced to meet the high market demands. Hence, in vitro culture techniques have been used as

*Corresponding author.
merrilynchan@gmail.com. Tel: 6565125. good alternatives to improve the mass production of $H$. niger plantlets.

A number of other species from the family Solanaceae have been proven to produce tropane alkaloids via root culture, either transformed hairy root culture or untransformed normal adventitious root production (Zehra et al., 1998; Pitta-Alvarez et al., 2000; Rothe et al., 2001; Biondi et al., 2002; Patterson and O'Hagan, 2002; Ninõ et al., 2003; Jordan et al., 2006; McCoy and O'Connor, 2008). Lai (2003) reported that tropane alkaloids could be obtained from micropropagated plantlets of $H$. niger. However, until now there is no detail study available on the production of tropane alkaloids in untransformed normal root culture of $H$. niger. Therefore, the present study was undertaken to establish the best medium and lighting condition for mass production of $\mathrm{H}$. niger untransformed normal roots, and to optimize the macronutrients for the production of $H$. niger roots.

\section{MATERIALS AND METHODS}

Plant material

Seeds of $H$. niger obtained from Richters (Canada) were used as starting material to produce in vitro plantlets. The seeds were disinfected by a two-stage surface-sterilization technique with 
Table 1. Effect of different explants on root induction and biomass production in $H$. niger on MS medium with 2.0 mg ${ }^{-1}$ IBA after four weeks of culture.

\begin{tabular}{lcc}
\hline Explant & Mean fresh weight of roots induced $(\mathbf{g}) \pm$ S.E. & Percentage of explants with root formation \pm S.E. \\
\hline Leaf & $0.87 \pm 0.16^{\mathrm{b}}$ & $83.3 \pm 5.34$ \\
Petiole & $1.73 \pm 0.23^{\mathrm{a}}$ & $86.1 \pm 6.55$ \\
Root & $0.40 \pm 0.08^{\mathrm{b}}$ & $100.0 \pm 0.00$ \\
\hline
\end{tabular}

Mean fresh weight followed by a same lowercase alphabet are not significantly different using Tukey HSD, ( $\leq \leq 0.05)$. The value represents mean \pm standard error.

Clorox® (Lai, 2003), by immersing for $15 \mathrm{~min}$ in $10 \%(\mathrm{v} / \mathrm{v})$ Clorox® containing 2 to 3 drops Tween 20 during the first stage, and for 5 $\min$ in $5 \%$ Clorox ${ }^{\circledR}$ in the second stage. Three rinses with sterile distilled water were executed following each stage of surface sterilization. The seeds were then inoculated on MS basal medium (Murashige and Skoog, 1962) with $30 \mathrm{~g} \mathrm{I}^{-1}$ sucrose and $8.0 \mathrm{~g} \mathrm{I}^{-}$ agar (Algas, Chiles) for germination. Seedlings were grown in vitro at $23 \pm 2^{\circ} \mathrm{C}$ with continuous fluorescent lighting of $32.5 \mu \mathrm{mol} \mathrm{m} \mathrm{m}^{-2} \mathrm{~s}^{-1}$. Leaf pieces $(0.5 \times 0.5 \mathrm{~cm})$, petioles and roots $(1 \mathrm{~cm})$ from six weeks old in vitro seedlings were used as explants to determine the best explant for root induction.

\section{Culture conditions}

All the explants were cultured on solid MS medium supplemented with $2.0 \mathrm{mg} \mathrm{I}^{-1} 3$-indolebutyric acid (IBA). The root induction medium was formulated according to Lai (2003). The fresh weight of the induced roots was determined after 4 week of culture using the Metler Toledo (Model Dragon 602) weighing scale. Morphology of the roots induced from the explants was observed under Light Microscope (Olympus SZ-PT Phaco).

To determine the appropriate root harvesting time, ten root pieces $(\sim 1.0 \mathrm{~cm})$ from the six weeks old in vitro seedlings were weighed and cultured in $100 \mathrm{ml}$ Erlenmeyer flask containing $20 \mathrm{ml}$ liquid MS medium supplemented with $0.5 \mathrm{mg} \mathrm{I}^{-1} \mathrm{IBA}$, the root proliferation medium (Lai, 2003). The cultures were placed on rotary shaker (G10 Gyrotary Shaker ${ }^{\circledR}$, New Brunswick Scientific Co. Inc., N.J., USA) at $120 \mathrm{rpm}$ for three or four weeks. Six experimental units were used for each duration and the experiment was repeated twice. After the intended duration, the roots were harvested and fresh weight was recorded. The data were analyzed using student ttest at $p \leq 0.05$.

In order to study the effect of subculture frequency and illumination on root proliferation, 10 root pieces from the induced roots were subcultured at 3 weeks intervals in liquid MS medium supplemented with $0.5 \mathrm{mg} \mathrm{I}^{-1}$ IBA. The root cultures were incubated under continuous light $\left(32.5 \mu \mathrm{mol} \mathrm{m} \mathrm{m}^{-2} \mathrm{~s}^{-1}\right)$ and in total darkness on rotary shaker at $120 \mathrm{rpm}$. Eight experimental units were used for each subculture cycle under different culture conditions. At each subculture cycle, the increase in fresh root biomass was determined after blotting away the liquid medium with filter paper. Morphology of the roots was observed under light microscope (Olympus SZ-PT Phaco)

To establish the best root proliferation medium, optimization process was carried out step-wise. The variables of the medium were MS macronutrients, myo-inositol, Fe-EDTA and sucrose. Three weeks old root cultures grown in liquid MS medium with 0.5 $\mathrm{mg}^{-1}$ IBA in dark were used for the optimization. The root pieces were cultured in $100 \mathrm{ml}$ Erlenmeyer flask containing $20 \mathrm{ml}$ culture medium modified after each stage of optimization. The MS medium were prepared in five different nutrient strength $(0,1 / 2,1 \times, 2 \times$ and $3 x)$. The MS macronutrients evaluated were ammonium nitrate
$\left(\mathrm{NH}_{4} \mathrm{NO}_{3}\right)$, potassium nitrate $\left(\mathrm{KNO}_{3}\right)$, calcium chloride dihydrate $\left(\mathrm{CaCl}_{2} .2 \mathrm{H}_{2} \mathrm{O}\right)$, magnesium sulphate heptahydrate $\left(\mathrm{MgSO}_{4} .7 \mathrm{H}_{2} \mathrm{O}\right)$ and potassium dihydrogen phosphate $\left(\mathrm{KH}_{2} \mathrm{PO}_{4}\right)$. The standard concentration of each macronutrient in MS basal medium was used as control. The same procedure was used to optimize each of the other variables namely myo-inositol $(0,5.55,11.1,22.2$ and 33.3 $\mathrm{mM})$, Fe-EDTA $(0,0.05,0.1,0.2$ and $0.3 \mathrm{mM})$ and sucrose $\left(0 \mathrm{~g} \mathrm{I}^{-1}\right.$, $15.0 \mathrm{~g} \mathrm{I}^{-1}, 30.0 \mathrm{~g} \mathrm{I}^{-1}, 60.0 \mathrm{~g}^{-1}$ and $\left.90.0 \mathrm{~g} \mathrm{l}^{-1}\right)$. Six experimental units were used for each variable. The cultures were continuously agitated at $120 \mathrm{rpm}$ on rotary shaker in dark. The roots were harvested after three weeks of culture and the fresh weight of the harvested roots was recorded. The dried mass was determined after the roots were air-dried at $25 \pm 2^{\circ} \mathrm{C}$ until constant weight was attained.

\section{Statistical analysis}

Each study was carried out using complete randomized design (CRD). The data were analyzed using one-way ANOVA followed by Tukey HSD test for mean com-parison at $p \leq 0.05$. The optimum concentration of each factor was determined with a polynomial regression curve based on the fresh root biomass using Curve Expert 1.3 and Microsoft ${ }^{\circledR}$ Excel.

\section{RESULTS AND DISCUSSION}

The effects of different factors such as explant types, illumination, incubation period and subculture frequency on induction and proliferation of roots in $H$. niger were studied. Normal untransformed root culture of $\mathrm{H}$. niger could be induced from three different explants (leaf, petiole and root) on MS medium supplemented with 2.0 $\mathrm{mg} \mathrm{I}^{-1}$ IBA. Root induction frequency from the petiole explants was $100 \%$ with significantly higher root biomass $(1.73 \pm 0.23 \mathrm{~g})$ as compared to the leaf explants $(0.87 \pm$ $0.16 \mathrm{~g})$ and root explants $(0.40 \pm 0.08 \mathrm{~g})$ after four weeks of culture (Table 1). Therefore, petiole was chosen as the explant of choice for root induction from $H$. niger. Earlier, petiole explant was also reported to be the best tissue for induction of hairy root cultures in Centella asiatica (Kim et al., 2007) and Saussurea medusa (Zhao et al., 2004).

MS medium supplemented with $2 \mathrm{mg} \mathrm{I}^{-1}$ IBA (as reported earlier by Lai, 2003) was used to induce roots from the different explants of $H$. niger. Subsequently, MS medium supplemented with $0.5 \mathrm{mg} \mathrm{I}^{-1}$ IBA was found to be better for root proliferation. Lai (2003) also observed that MS medium supplemented with $2.0 \mathrm{mg} \mathrm{I}^{-1}$ IBA was 


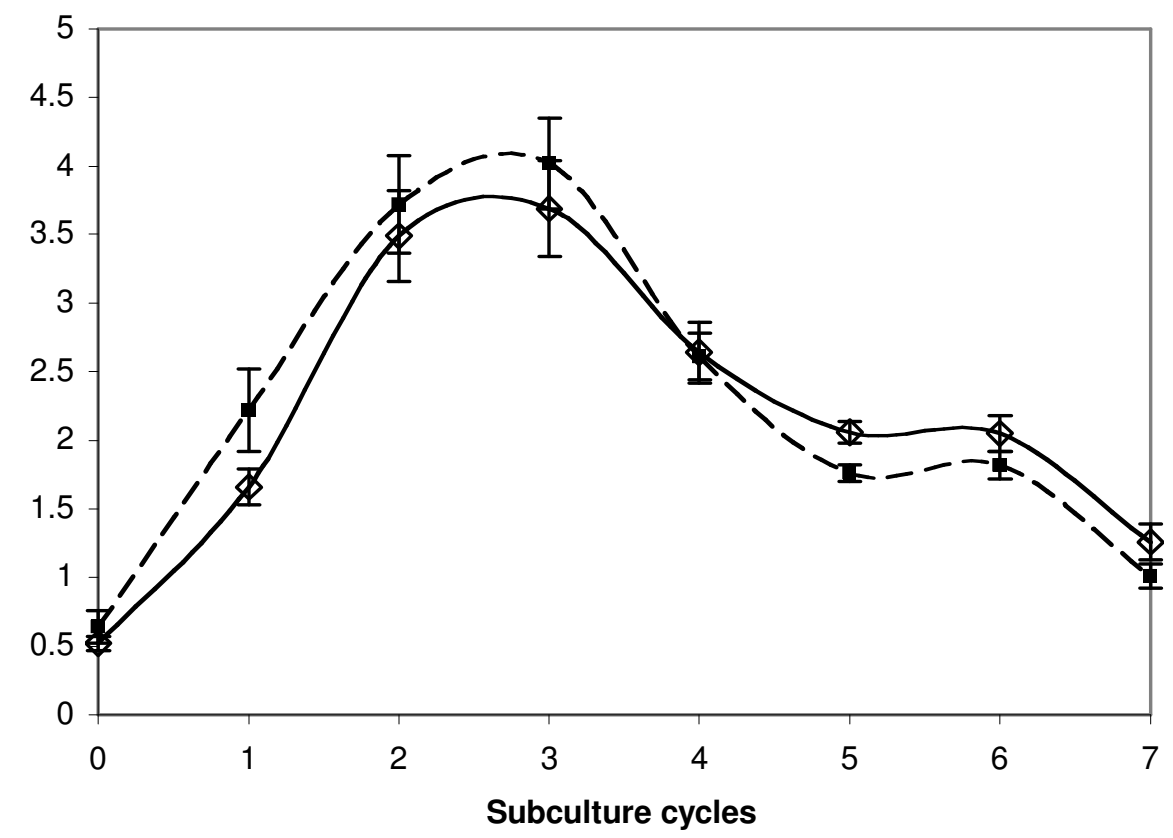

$\_$Continuous light $\_\rightarrow--$ Total darkness

Figure 1. Effect of subculture cycle and light on $H$. niger root biomass production in liquid MS supplemented with $0.5 \mathrm{mg} \mathrm{I}^{-1}$ IBA.

not suitable for root proliferation in $\mathrm{H}$. niger because it caused abnormal root formation and resulted in growth retardation. Hence liquid MS medium with a lower concentration of IBA $\left(0.5 \mathrm{mg} \mathrm{I}^{-1}\right)$ was used for optimization of root culture of $\mathrm{H}$. niger in the subsequent experiments.

\section{Root harvesting time}

Culture duration for root growth is mostly dependent on the plant species. In present case, results indicated that the amount of root biomass produced was not significantly different for three $(2.19 \pm 0.28 \mathrm{~g})$ and four weeks $(2.32 \pm 0.21 \mathrm{~g})$ of root cultures. Therefore, three weeks duration was chosen as the best harvesting time for the $H$. niger root cultures. In other plant species also different culture period for optimum growth has been reported such as 3 weeks for Azadirachta indica (Satdive et al., 2007) and Hyoscyamus muticus (Medina-Bolivar and Flores, 1995), 4 weeks for Datura stramonium (Maldonado-Mendoza et al., 1993).

\section{Effect of light on root proliferation}

Presence or absence of light was found to have effect during root induction and root proliferation. The amount of root induced from the petiole explants cultured on MS medium supplemented with $2.0 \mathrm{mg} \mathrm{l}^{-1}$ IBA and incubated in light was significantly higher $(0.86 \pm 0.12$ g/explant $)$ compared to that cultured in total darkness $(0.45 \pm 0.05$ g/explant) after four weeks of culture. However, during root proliferation, the roots cultured in liquid MS medium supplemented with $0.5 \mathrm{mg} \mathrm{I}^{-1}$ IBA under total darkness exhibited a better root biomass production as compared to those exposed to continuous light from the first to third subcultures. But the root cultures incubated under continuous light showed better proliferation rate after the fifth subculture cycles. The highest root biomass was obtained at the third subculture regardless under continuous light $(3.69 \pm 1.00 \mathrm{~g})$ or total darkness condition (4.02 $\pm 0.94 \mathrm{~g})$, which was approximately 369 times higher from its initial weight (Figure 1). Therefore, the continuous light condition was selected for root induction while total darkness condition was used for root proliferation.

\section{Optimization of root proliferation medium}

Medium composition is an important factor affecting in vitro growth of plants or organs. In the present study, five macronutrients $\left(\mathrm{NH}_{4} \mathrm{NO}_{3}, \mathrm{KNO}_{3}, \quad \mathrm{CaCl}_{2} .2 \mathrm{H}_{2} \mathrm{O}\right.$, $\mathrm{MgSO}_{4} .7 \mathrm{H}_{2} \mathrm{O}$ and $\mathrm{KH}_{2} \mathrm{PO}_{4}$ ) were modified to optimize production of $\mathrm{H}$. niger untransformed roots in shake flask system. Results revealed that different concentration of these macronutrients added into the root proliferation medium affected differently the fresh and dried biomass of $H$. niger roots after three weeks of culture (Figure 2). 

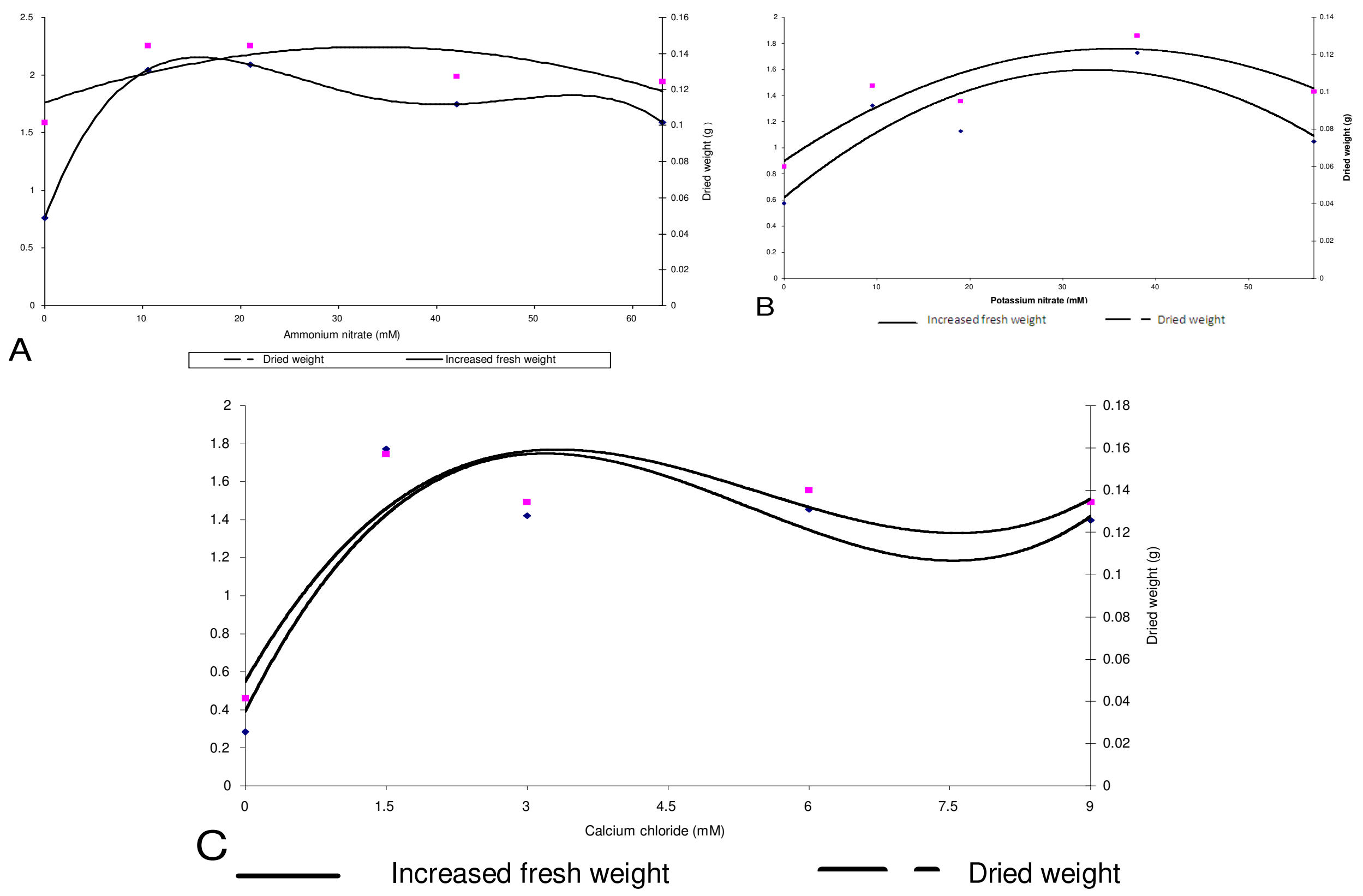


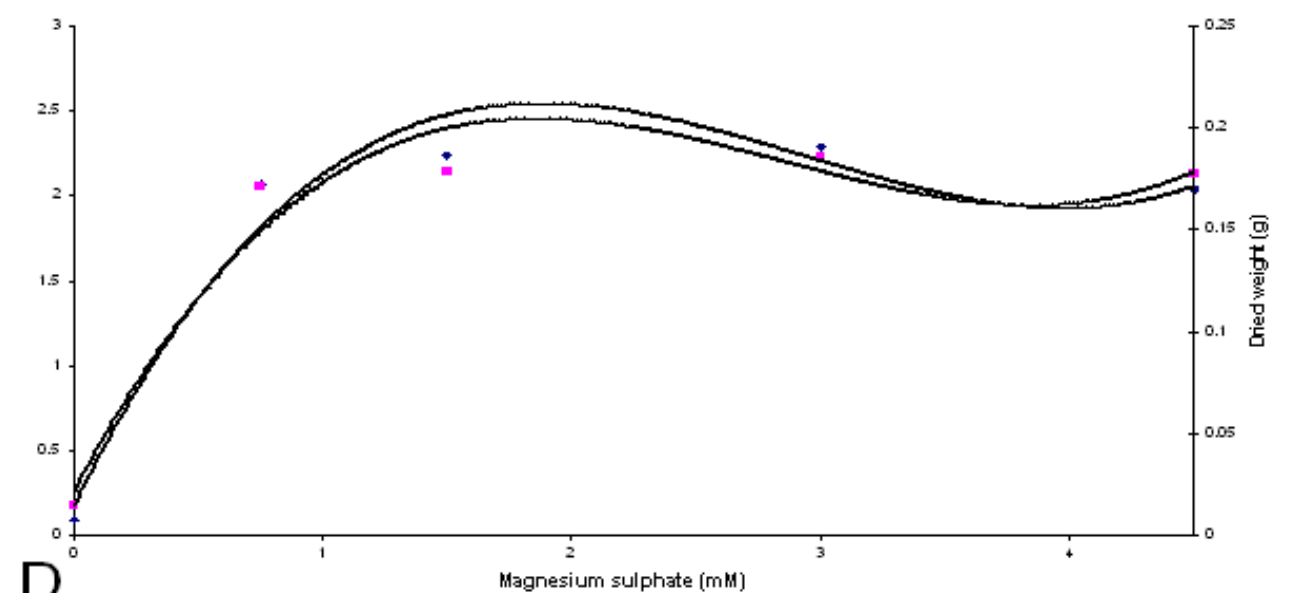

D

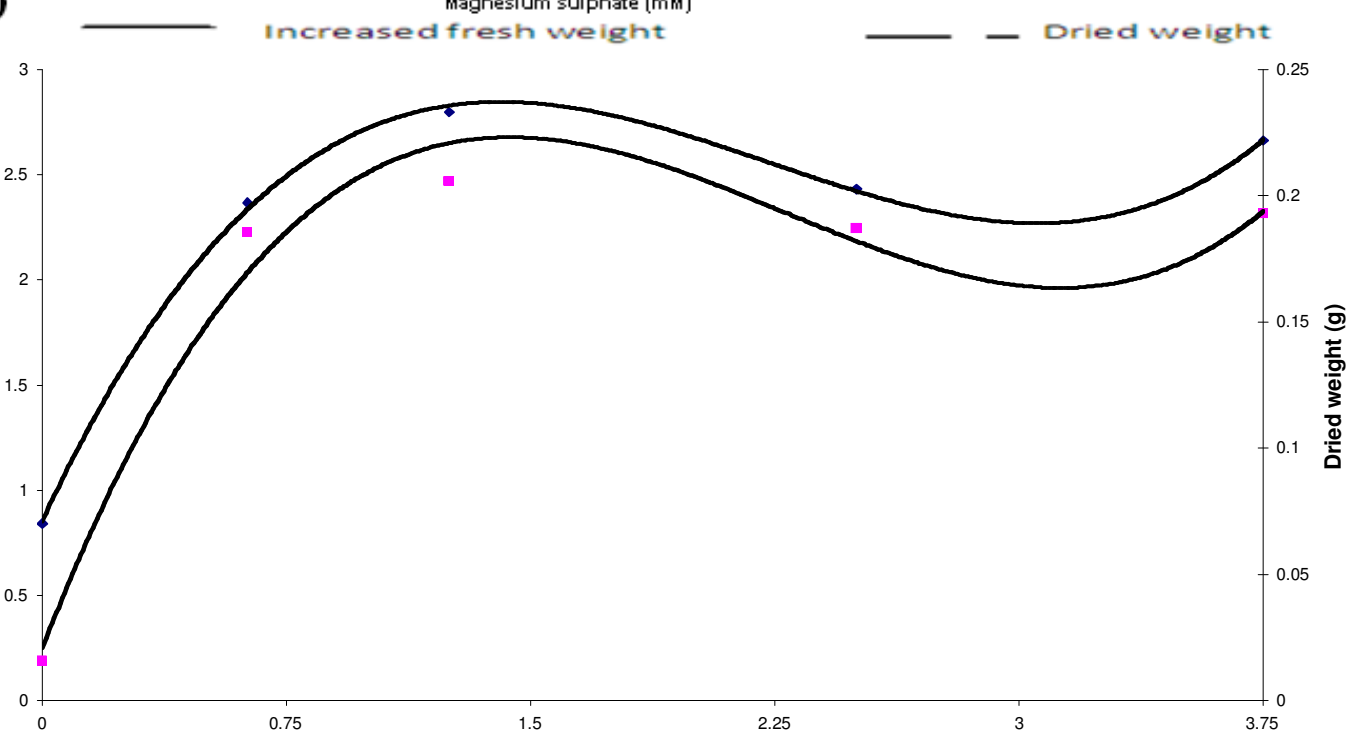

E

Potassium dihydrogen phosphate (mM)

Figure 2. Effect of different macronutrients on roots biomass production in $\mathrm{H}$. niger after 3 weeks of culture in $20 \mathrm{ml}$ modified MS medium supplemented with $0.5 \mathrm{mg} \mathrm{I}^{-1}$ IBA (A) Effect of different conc. of $\mathrm{NH}_{4} \mathrm{NO}_{3}(\mathrm{~B})$ Effect of different conc. of $\mathrm{KNO}_{3}$ with $15.0 \mathrm{mM} \mathrm{NH}_{4} \mathrm{NO}_{3}$ (C) Effect of different conc. of $\mathrm{CaCl}_{2} .2 \mathrm{H}_{2} \mathrm{O}$ with 15.0 $\mathrm{mM} \mathrm{NH}_{4} \mathrm{NO}_{3}$ and $33.1 \mathrm{mM} \mathrm{KNO}_{3}$ (D) Effect of different conc. of $\mathrm{MgSO}_{4} .7 \mathrm{H}_{2} \mathrm{O}$ with $15.0 \mathrm{mM} \mathrm{NH}_{4} \mathrm{NO}_{3}, 33.1 \mathrm{mM}$ $\mathrm{KNO}_{3}$ and $3.19 \mathrm{mM} \mathrm{CaCl}_{2} .2 \mathrm{H}_{2} \mathrm{O}$ (E) Effect of different conc. of $\mathrm{KH}_{2} \mathrm{PO}_{4}$ with $15.0 \mathrm{mM} \mathrm{NH}_{4} \mathrm{NO}_{3}, 33.1 \mathrm{mM}$ $\mathrm{KNO}_{3}, 3.19 \mathrm{mM} \mathrm{CaCl}_{2} .2 \mathrm{H}_{2} \mathrm{O}$ and $1.9 \mathrm{mM} \mathrm{MgSO}_{4} .7 \mathrm{H}_{2} \mathrm{O}$ 
Compared to the medium devoid of $\mathrm{NH}_{4} \mathrm{NO}_{3}$, the growth of roots cultured in MS medium supplemented with $\mathrm{NH}_{4} \mathrm{NO}_{3}$ was enhanced. Addition of 10.5 and 21.0 $\mathrm{mM} \mathrm{NH} \mathrm{NO}_{3}$ resulted in higher fresh root biomass $(2.05 \pm$ $0.23 \mathrm{~g}$ and $2.09 \pm 0.07 \mathrm{~g})$ and dry weight $(0.14 \pm 0.01 \mathrm{~g})$. However, further increment of $\mathrm{NH}_{4} \mathrm{NO}_{3}$ concentration $(63.0 \mathrm{mM})$ decreased the root production, with the lowest fresh root biomass $(1.58 \pm 0.18 \mathrm{~g})$ and dried root biomass $(0.12 \pm 0.01 \mathrm{~g})$ (Figure 2A). Based on the polynomial curve of fresh root biomass, $15.00 \mathrm{mM} \mathrm{NH}{ }_{4} \mathrm{NO}_{3}$ concentration was found optimum for root production in $\mathrm{H}$. niger, which is lower than its standard concentration in MS medium $(21.0 \mathrm{mM})$. Low concentration of $\mathrm{NH}_{4} \mathrm{NO}_{3}$ was also preferred in the hairy root cultures of Bupleurum falcatum and Artemisia annua (Ahn et al., 2006; Weathers et al., 1997). Franklin and Dixon (1994) also reported that lower $\mathrm{NH}_{4}^{+}$to $\mathrm{NO}_{3}{ }^{-}$ratio in the medium was favorable for cell growth however, high level of nitrogen caused toxic effect. Increased nitrate: ammonia level to 5:1 in culture medium for Azadirachta indica cell suspension culture enhanced the cell biomass production (Sujanya et al., 2008).

Addition of $\mathrm{KNO}_{3}$ in the proliferation medium also enhanced the root production in $\mathrm{H}$. niger (Figure 2B). The proliferation medium without $\mathrm{KNO}_{3}$ produced less root biomass $(0.58 \pm 0.12 \mathrm{~g} \mathrm{FW}$ and $0.06 \pm 0.01 \mathrm{~g} \mathrm{DW})$. However, addition of $38.0 \mathrm{mM} \mathrm{KNO}_{3}$ in the proliferation medium increased the biomass to $1.72 \pm 0.38 \mathrm{~g} \mathrm{FW}$ and $0.13 \pm 0.02 \mathrm{~g} \mathrm{DW}$. Potassium nitrate is an important salt in plant and tissue culture medium for prevention of medium pH fluctuation (Wong, 2003). Besides that, potassium ion $\left(\mathrm{K}^{+}\right)$serves as a major contributor to osmotic potential, a specific requirement for protein synthesis and an activator for particular enzyme systems while nitrogen ion from this salt is a vital element in DNA, RNA, amino acids and protein structure. Herein, $33.1 \mathrm{mM}$ $\mathrm{KNO}_{3}$ concentration, 1.75 times the standard $19.0 \mathrm{mM}$ of $\mathrm{KNO}_{3}$ in MS medium, was found to be optimum for $\mathrm{H}$. niger root production on the basis of polynomial curve of fresh root biomass. Nussbaumer et al. (1998) also reported that higher concentration $(75 \mathrm{mM})$ of $\mathrm{KNO}_{3}$ enhanced hairy root growth in Datura candida $\times D$. aurea. However, Chae et al. (2000) found that the ratio of $\mathrm{KNO}_{3}$ : $\mathrm{NH}_{4} \mathrm{H}_{2} \mathrm{PO}_{4}(2500: 150 \mathrm{mg} / \mathrm{L})$ was the best for hairy root production in Polygonum tinctorium.

The varying amount of $\mathrm{CaCl}_{2} \cdot 2 \mathrm{H}_{2} \mathrm{O}$ in the root proliferation medium affected the root growth in $\mathrm{H}$. niger. Lesser root biomass $(0.28 \pm 0.05 \mathrm{~g} \mathrm{FW}$ and $0.04 \pm 0.01 \mathrm{~g}$ DW) was produced in the medium without $\mathrm{CaCl}_{2} \cdot 2 \mathrm{H}_{2} \mathrm{O}$ while higher root biomass (FW $1.77 \pm 0.22 \mathrm{~g}$; DW $0.16 \pm$ $0.01 \mathrm{~g}$ and FW $1.42 \pm 0.24 \mathrm{~g}$; DW $0.13 \pm 0.01 \mathrm{~g}$ ) was obtained from the proliferation medium supplemented with $1.5 \mathrm{mM}$ and $3.0 \mathrm{mM} \mathrm{CaCl} 2.2 \mathrm{H}_{2} \mathrm{O}$, respectively. However, $\mathrm{CaCl}_{2} .2 \mathrm{H}_{2} \mathrm{O}$ concentration between 3.0 and $7.5 \mathrm{mM}$ adversly affected the root biomass production while still higher concentration of $\mathrm{CaCl}_{2} \cdot 2 \mathrm{H}_{2} \mathrm{O}(>7.5 \mathrm{mM})$ further improved the root biomass production (Figure $2 \mathrm{C}$ ). As revealed by the polynomial curve, optimized concentration of $\mathrm{CaCl}_{2} .2 \mathrm{H}_{2} \mathrm{O}$ for $\mathrm{H}$. niger root proliferation was $3.19 \mathrm{mM}$ which is almost equal to the basic concentration of $3.00 \mathrm{mM}$ in the basal MS medium. It could be deduced that the presence of calcium was crucial for the growth of $H$. niger roots but the calcium content did not have strong effect on the root growth. This finding is in tune with that of Luthfi et al. (2004), who reported MS medium with 3 $\mathrm{mM} \mathrm{CaCl} 2.2 \mathrm{H}_{2} \mathrm{O}$ to produce higher cell biomass in Eurycoma longifolia. However, Ghosh et al. (2006) reported increased root growth in Gloriosa superba with higher concentration $(10 \mathrm{mM})$ of $\mathrm{CaCl}_{2}$ in the liquid $\mathrm{NB}$ medium.

$\mathrm{MgSO}_{4} .7 \mathrm{H}_{2} \mathrm{O}$ also played an important role in root production in $\mathrm{H}$. niger. Presence of $\mathrm{MgSO}_{4} .7 \mathrm{H}_{2} \mathrm{O}$ in the root proliferation medium significantly increased root biomass production as compared to the medium without $\mathrm{MgSO}_{4} .7 \mathrm{H}_{2} \mathrm{O}$. Addition of 0.75 to $4.50 \mathrm{mM} \mathrm{MgSO}{ }_{4} \cdot 7 \mathrm{H}_{2} \mathrm{O}$ significantly increased root biomass $(2.04 \pm 0.16$ to $2.28 \pm$ $0.22 \mathrm{~g} \mathrm{FW}$ and $0.17 \pm 0.01$ to $0.19 \pm 0.01 \mathrm{~g} \mathrm{DW}$, respectively) (Figure 2D). Magnesium being critical for functioning of enzymes, it is an integral component of chlorophyll molecule. $\mathrm{MgSO}_{4} .7 \mathrm{H}_{2} \mathrm{O}$ at the rate of $1.9 \mathrm{mM}$ was found to be optimum for root production in $\mathrm{H}$. niger which is slightly higher than its standard concentration $(1.5 \mathrm{mM})$ in $\mathrm{MS}$ medium but still in the range of $\mathrm{Mg}^{2+}$ concentration that is used in various culture media. Our results contradicted with Jacob and Malpathak (2005) who reported that half strength of magnesium sulphate in MS medium increased the root growth and solasodine production in hairy root culture of Solanum khasianum. However, Luthfi et al. (2004) reported that MS medium supplemented with one-third concentration of $\mathrm{MgSO}_{4} .7 \mathrm{H}_{2} \mathrm{O}$ in the MS medium was optimum for cell growth in Eurycoma longifolia.

The present study also indicated that $\mathrm{KH}_{2} \mathrm{PO}_{4}$ is essential for roots proliferation in $\mathrm{H}$. niger. Addition of $\mathrm{KH}_{2} \mathrm{PO}_{4}$ between 1.5 to $3.0 \mathrm{mM}$ in the root proliferation medium reduced the root biomass; however, higher concentration of $\mathrm{KH}_{2} \mathrm{PO}_{4}(\geq 3.0 \mathrm{mM})$ increased the root biomass (Figure

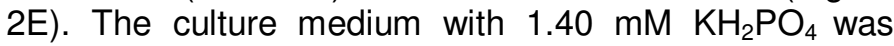
found to be optimum for root growth which is slightly higher than its standard concentration $(1.25 \mathrm{mM})$ in basal MS medium. The concentration was similar to the absolute amount that is required for growth in plant tissue culture (Wong, 2003). Generally, higher level of phosphate enhanced cell growth and increased biomass production in some species, whereas it adversely affected the secondary metabolite accumulation in different plant species (Woo et al., 1995; Weathers et al., 1997; Trejo-Tapia et al., 2003; Sujanya et al., 2008; Amdoun et al., 2009; Pavlov et al., 2009).

The modified MS medium supplemented with the optimized concentrations of macronutrients $(15.00 \mathrm{mM}$ $\mathrm{NH}_{4} \mathrm{NO}_{3}, 33.10 \mathrm{mM} \mathrm{KNO} 3,3.19 \mathrm{mM} \mathrm{CaCl} 2.2 \mathrm{H}_{2} \mathrm{O}, 1.90$

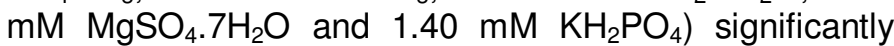
enhanced root biomass production $(2.32 \pm 0.11 \mathrm{~g} \mathrm{FW}$ 

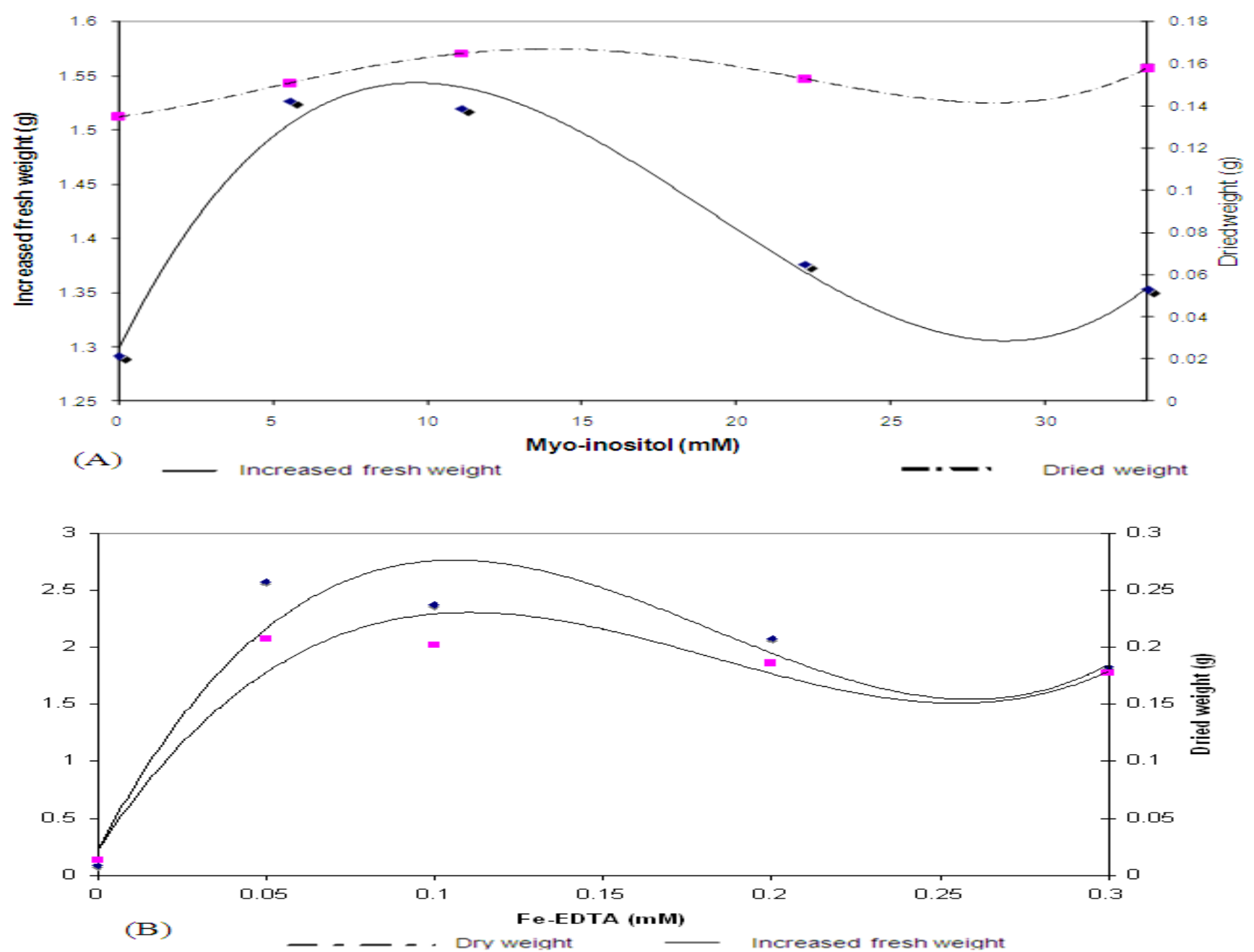

Figure 3. Effect of myo-inositol (A) and Fe-EDTA (B) on production of root biomass in $\mathrm{H}$. niger cultured in $20 \mathrm{ml}$ modified MS medium containing $15.0 \mathrm{mM} \mathrm{NH}_{4} \mathrm{NO}_{3}+33.1 \mathrm{mM} \mathrm{KNO}_{3}+3.19 \mathrm{mM} \mathrm{CaCl}_{2} .2 \mathrm{H}_{2} \mathrm{O}+1.9 \mathrm{mM} \mathrm{MgSO} 4.7 \mathrm{H}_{2} \mathrm{O}+1.40 \mathrm{mM} \mathrm{KH}_{2} \mathrm{PO}_{4}$ and $0.5 \mathrm{mg} \mathrm{I}^{-1}$ IBA after 3 weeks of culture.

and $0.20 \pm 0.02 \mathrm{~g} \mathrm{DW}$ ) as compared to the basal MS medium (1.61 $\pm 0.06 \mathrm{~g} \mathrm{FW}$ and $0.12 \pm 0.02 \mathrm{~g} \mathrm{DW})$ after three weeks of culture. The modified MS medium supplemented with optimized macronutrient but without myo-inositol produced equally good root biomass (1.29 \pm $0.13 \mathrm{~g} \mathrm{FW}$ and $0.14 \pm 0.01 \mathrm{~g} \mathrm{DW})$. Addition of $5.55 \mathrm{mM}$ and $11.1 \mathrm{mM}$ myo-inositol into the proliferation medium resulted into a similar amount root biomass production $(1.53 \pm 0.10 \mathrm{FW} ; 0.15 \pm 0.01 \mathrm{~g} \mathrm{DW}$ and $1.52 \pm 0.13$ $\mathrm{FW} ; 0.17 \pm 0.01 \mathrm{~g} \mathrm{DW}$, respectively). But the higher concentrations of myo-inositol $(\geq 11.1 \mathrm{mM})$ significantly reduced the root biomass production (Figure $3 \mathrm{~A}$ ). The optimized concentration of myo-inositol as determined from the polynomial curve was found to be $9.6 \mathrm{mM}$. This concentration of myo-inositol is slightly lower than the standard concentration (11.1 mM) of myo-inositol in MS medium. Myo-inositol is the only stereoisomer of inositol and it has significant biological importance in auxin storage and transport, signal transduction, phytic acid biosynthesis, cell wall biosynthesis and the production of stress related molecules (Styer, 2000).

Absence of Fe-EDTA in the culture medium inhibited root biomass production $(0.09 \pm 0.03 \mathrm{~g} \mathrm{FW}$ and $0.01 \pm 0.00 \mathrm{~g} \mathrm{DW})$. However, addition of $0.05 \mathrm{mM}$ and $0.10 \mathrm{mM}$ Fe-EDTA in the root proliferation medium increased the root biomass production $(2.58 \pm 0.17 \mathrm{~g} \mathrm{FW}$; $0.21 \pm 0.01 \mathrm{~g} \mathrm{DW}$ and $2.37 \pm 0.21 \mathrm{~g} \mathrm{FW} ; 0.20 \pm 0.01 \mathrm{~g}$ DW, respectively). Further increase in Fe-EDTA concentration adversely affected root production (Figure $3 \mathrm{~B}$ ). Based on the polynomial curve, $0.10 \mathrm{mM}$ Fe-EDTA was found to be optimum for roots production in $H$. niger which is equal to the concentration of Fe-EDTA in the basal MS medium. Iron is an essential micronutrient and its presence in the form of chelating agent (EDTA) complex enhances rooting due to auxin effect, but at higher concentration it causes toxicity (George et al., 


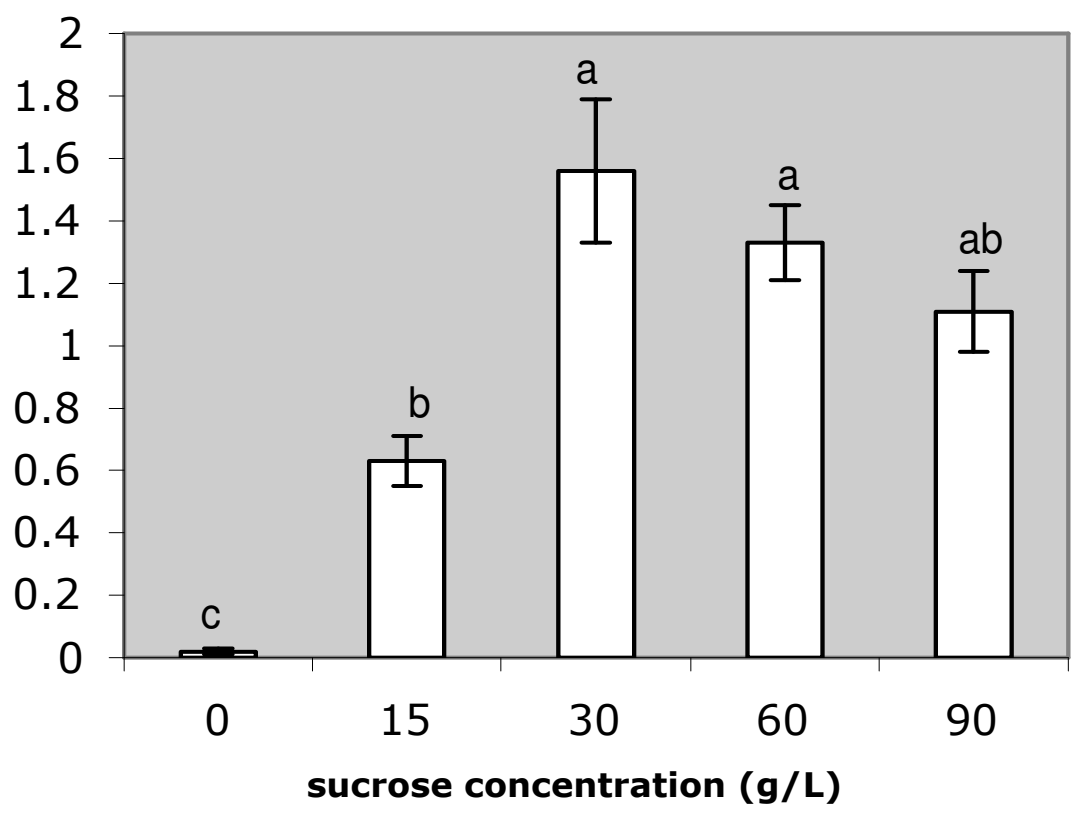

Figure 4. Effect of sucrose concentration on production of fresh root biomass in $H$. niger in modified MS (optimized macronutrients) with $9.6 \mathrm{mM}$ myoinositol, 0.10 $\mathrm{mM}$ Fe-EDTA and $0.5 \mathrm{mg} \mathrm{I}^{-1}$ IBA after 3 weeks of culture. The mean values followed by different lowercase alphabet are significantly different (Tukey test, $\mathrm{p} \leq 0.05)$. Vertical bars represent increase fresh weigh $(\mathrm{g})$.

2007; Mairet et al., 2009).

Absence of sucrose in the culture medium adversely affected root production. However, addition of $15 \mathrm{~g} \mathrm{I}^{-1}$ and $30 \mathrm{~g} \mathrm{I}^{-1}$ sucrose in the culture medium produced good root biomass (fresh weight $0.63 \pm 0.09 \mathrm{~g}$ and $1.56 \pm 0.23 \mathrm{~g}$ respectively). Further increase in sucrose concentration $\left(60 \mathrm{~g} \mathrm{I}^{-1}\right.$ and $90 \mathrm{~g} \mathrm{I}^{-1}$ ) adversely affected root biomass production $(1.33 \pm 0.12 \mathrm{~g}$ and $1.11 \pm 0.14 \mathrm{~g}$ FW, respectively) (Figure 4). The correlation between rate of biomass production and sugar consumption was studied by Wu and Zhong (1999). Sucrose generally exerts osmotic pressure and influences productivity of plant as a carbon source. However, the requirement of source is different and varies according to plant species (Liu and Cheng, 2008). In this study, $30 \mathrm{~g} \mathrm{I}^{-1}$ sucrose was found optimum for root production in $H$. niger. All the roots grown in presence of sucrose were normal, while the roots grown in the medium devoid of sucrose were short and retarded. Our results are in tune with Kevers et al. (1999), who reported $30 \mathrm{~g} \mathrm{I}^{-1}$ sucrose to be optimum for root biomass production in Panax ginseng and $P$. quinquefolium.

Thus, based on the results obtained we recommend modified MS medium containing $15.0 \mathrm{mM} \mathrm{NH}_{4} \mathrm{NO}_{3}, 33.1$ $\mathrm{mM} \mathrm{KNO}{ }_{3}, 3.19 \mathrm{mM} \mathrm{CaCl} .2 \mathrm{H}_{2} \mathrm{O}, 1.9 \mathrm{mM} \mathrm{MgSO}{ }_{4} .7 \mathrm{H}_{2} \mathrm{O}$ and $1.4 \mathrm{mM} \mathrm{KH}_{2} \mathrm{PO}_{4}, 9.6 \mathrm{mM}$ myo-inositol, $0.1 \mathrm{mM}$ FeEDTA, 3\% sucrose along with the standard concentration of the other constituents of the basal MS medium and 0.5 $\mathrm{I}^{-1} \mathrm{mg}$ IBA for maximum root biomass production in $\mathrm{H}$. niger.

\section{ACKNOWLEDGEMENT}

We thank University Sains Malaysia for research facilities and the Malaysian government for research grant.

\section{REFERENCES}

Ahn JC, Chong WS, Kim YS, Hwang B (2006). Optimization of the sucrose and ion concentration for saikosaponin production in hairy root culture of Bupleurum falcatum. Biotechnol Bioproc E. 11:121126.

Amdoun R, Khelifi L, Khelifi-Slaoui M, Amroune S, Benyoussef E-H, Thi DV, Assaf-Ducrocq A, Gontier E (2009). Influence of minerals and elicitation on Datura stramonium L. tropane alkaloid production: modelization of the in vitro biochemical response. Plant Sci., 177: 8187.

Biondi S, Scaramagli S, Oksman-Caldentey KM, Poli F (2002). Secondary metabolism in root and callus cultures of Hyoscyamus muticus L.: the relationship between morphological organization and response to methyl jasmonate. Plant Sci., 163: 563-569.

Chae Y-A, Yu H-S, Song J-Y, Chun H-K, Park S-U (2000). Indigo production in hairy roots of Polygonum tinctorium Lour. Biotechnol Lett., 22: 1527-1530.

Enriz RD (2005). The legacy of the past, the reality of the present and the hopes of the future. J Mol Struct., 731: 163-172.

Franklin CI, Dixon RA (1994). Initiation and maintenance of callus and cell suspension cultures. In Dixon, R.A., Gonzales, R.A. (eds), Plant cell culture- a practical approach, 2nd edition. IRL Press Oxford.

George EF, Hall MA, De Klerk GJ (2007). Plant Propagation by tissue culture $3^{\text {rd }}$ Edition. Volume 1 the background Springer.

Ghosh S, Ghosh B, Jha S (2006). Aluminium chloride enhances colchicine production in root cultures of Gloriosa superba. Biotechnol Lett., 28: 497-503.

Harrison AP, Bartels EM (2006). A modern appraisal of ancient etruscan herbal practices. Am. J. Pharmacol .Toxicol., 1(2): 26-29. 
Hashimoto T, Hayashi A, Amano Y, Kohno J, Iwanari H, Usuda S, Yamada Y (1991). Hyoscyamine 6ß-hydroxylase, an enzyme involved in tropane alkaloid biosynthesis, is localized at the pericycle of the root. J. Biol. Chem., 266: 4648-4653.

Jacob A, Malpathak N (2005). Manipulation of MS and B5 components for enhancement of growth and solasodine production in hairy root cultures of Solanum khasianum Clarke. Plant Cell Tiss. Org., 80: 247257.

Jordan M, Humam M, Bieri S, Christen P, Poblete E, Muñoz O (2006). In vitro shoot and root organogenesis, plant regeneration and production of tropane alkaloids in some species of Schizanthus. Phytochem., 67: 570-578.

Kevers C, Jacques P, Thonart P, Gaspar T (1999). In vitro root cultures of Panax ginseng and P. quinquefolium. Plant Growth Regul., 27: 173-178.

Kim OT, Bang KH, Shin YS, Lee MJ, Jung SJ, Hyun DY, Kim YC, Seong NS, Cha SW, Hwang B (2007). Enhanced production of asiaticoside from hairy root cultures of Centella asiatica (L.) urban elicited by methyl jasmonate. Plant Cell Rep., 26: 1941-1949.

Lai EM (2003). Micropropagation, callus induction and root culture of Hyoscyamus niger L., a temperate medicinal plant. M. Sc. Thesis, USM: School of Biological Sciences.

Li GQ, Duke CC, Roufigalis BD (2003). The quality and safety of traditional chinese medicines. Australian Prescriber., 26: 128-130.

Liu CZ, Cheng XY (2008). Enhancement of phenylethanoid glycosides biosynthesis in cell cultures of Cistanche deserticola by osmotic stress. Plant Cell Rep., 27: 357-362.

Luthfi AMS, Chan LK, Boey PL (2004). Selection of cell source and the effect of $\mathrm{pH}$ and MS macronutrients on biomass production in cell cultures of Tongkat Ali (Eurycome longifolia Jack.). J Plant Biotechnol., 5: 131-135.

Mairet F, Sierra J, Glorian V, Villon P, Shakourzadeh K, Boitel-Conti M (2009). A new approach to define optimized range of medium composition for enhancement of hairy root production in fed-batch process. Biotechnol. Bioproc. E., 32: 257-265.

Maldonado-Mendoza IE, Ayora-Talavera T, Loyola-Vargas VM (1993). Establishment of hairy root cultures of Datura stramonium. Plant Cell Tiss Org., 33: 321-329.

McCoy E, O'Connor SE (2008). Natural products from plant cell cultures. Prog. Drug Res., 65: 330-370.

Medina-Bolivar F, Flores HE (1995). Selection and cinnamoyl putrescine overproduction in cell and root cultures of Hyoscyamus muticus. Plant Physiol., 108: 1553-1560.

Murashige T, Skoog F (1962). A revised medium for rapid growth and bioassays with tobacco tissue cultures. Physiol. Plant, 15: 473-297.

Ninõ J, Gallego CM, Correa YM, Mosquera OM (2003). Production of scopolamine by normal root cultures of Brugmansia candida. Plant Cell Tiss Org., 74: 289-291.

Nussbaumer P, Kapétanidis I, Christen P (1998). Hairy roots of Datura candida $\times D$. aurea: effect of culture medium composition on growth and alkaloid biosynthesis. Plant Cell Rep., 17: 405-409.

Patterson S, O'Hagan D (2002). Biosynthetic studies on the tropane alkaloid hyoscyamine in Datura stramonium; hyoscyamine is stable to in vivo oxidation and is not derived from Littorine via A Vicina interchange process. Phyotochemistry, 61: 323-329.

Pavlov A, Berkov S, Weber J, Bley T (2009). Hyoscyamine biosynthesis in Datura stramonium hairy root in vitro systems with different ploidy levels. Appl. Biochem. Biotechnol., 157: 210-225.
Pitta-Alvarez SI, Spollansky TC, Giuletti AM (2000). Scopolamine and hyoscyamine production by hairy root cultures of Brugmansia candida: influence of calcium chloride, hemicellulase and theophylline. Biotechnol. Lett., 22: 1653-1656.

Rothe G, Garske U, Dräger B (2001). Calystegines in root cultures of Atropa belladonna respond to sucrose, not to elicitation. Plant Sci., 160: 1043-1053.

Sajeli B, Sahai M, Suessmuth R, Asai T, Hara N, Fujimoto Y (2006). Hyosgerin, a new optically active coumarinolignan, from the seeds of Hyoscyamus niger. Chem. Pharm. Bull., 54: 538-541.

Satdive RK, Fulzele DP, Eapen S (2007). Enhanced production of azadirachtin by hairy root cultures of Azadirachta indica A. Juss by elicitation and optimization. J. Biotechnol., 128: 281-289.

Schultes RE, Smith EW (1976). Hallucinogenic plants: A golden guide. Golden Press. New York.

Styer JC (2000). Regulating inositol biosynthesis in plants: myo-inositol phosphate synthase and myo-inositol monophosphatase. M.Sc. in biochemistry, thesis. Faculty of Virginia Polytechnic Institute and State University of Virginia.

Sujanya S, Devi BP, Sai I (2008). In vitro production of azadirachtin from cell suspension cultures of Azadirachta indica. J. Biosci., 33: 113-120.

Trejo-Tapia G., Arias-Castro C, Rodríguez-Mendiola M (2003). Influence of the culture medium constituents and inoculum size on the accumulation of blue pigment and cell growth of Lavandula spica. Plant Cell Tiss. Org., 72: 7-12.

Vike GM, Ufberg JW, Harrigan RA, Chan TC (2008). Evaluation and treatment of acute urinary retention. J. Emerg. Med., 35: 193-198.

Weathers PJ, Hemmavanh DD, Walcerz DB, Cheetham RD, Smith TC (1997). Interactive effects of nitrate and phosphate salts, sucrose and inoculum culture age on growth and sesquiterpene production in Artemisia annua hairy root cultures. In Vitro Cell Dev. Biol. Plant,, 33: 306-312.

Winston D (1994). An introduction to herbal medicine, http://www.herbaltherapeutics.net/HerbalMedicinelntroduction.pdf, $25^{\text {th }}$ April 2010. Wolter, K. E. and Skoog, F. (1966). Nutritional Requirements of Fraxinus Callus Cultures. Am. J. Bot.. 53: 263-269.

Wong K (2003). Enhancement of cell growth and saponin production in Panax ginseng cell culture by nutrient feeding and elicitation. master of philosophy thesis, The Hong Kong Polytechnic University.

Woo HS, Park JM, Yang J-W (1995). Production of scopolamine by normal root culture of Hyoscyamus niger. Biotechnol. Lett., 17: 921926.

Wu J, Zhong J-J (1999). Production of ginseng and its bioactive components in plant cell culture: current technological and applied aspects. J. Biotechnol., 68: 89-99.

Zehra M, Banerjee S, Naqvi AA, Kumar S (1998). Variation in the growth and alkaloid production capability of the hairy roots of Hyoscyamus albus, $H$. muticus and their somatic hybrid. Plant Sci., 136: 93-99.

Zhao D, Fu C, Chen Y, Ma F (2004). Transformation of Saussurea medusa for hairy roots and jaceosidin production. Plant Cell Rep., 23: 468-474. 